\title{
Cell surface structures in osmotically fragile mutants of Saccharomyces cerevisiae
}

\author{
Marie Kopecká, ${ }^{1 *}$ Miroslav Gabriel, ${ }^{1}$ OldřICh NeČas, ${ }^{1}$ Augustin Svoboda ${ }^{1}$ and \\ P. V. VENKOV ${ }^{2}$ \\ ${ }^{1}$ Department of Biology, Faculty of Medicine, Masaryk University, 66243 Brno, Czechoslovakia \\ 2 Institute of Molecular Biology, Bulgarian Academy of Sciences, 1113 Sofia, Bulgaria
}

(Received 30 November 1990; revised 11 February 1991; accepted 21 February 1991)

\begin{abstract}
Mutants of Saccharomyces cerevisiae characterized by osmotic fragility showed a marked fibrillar structure on the inner wall surface when studied by two electron microscopic techniques, i.e. freeze-etching of whole native cells and metal shadowing of isolated cell walls. The walls of the mutant cells were more permeable to macromolecules than were those of the wild-type parental strain. The synthesis and assembly of $(1 \rightarrow 3)$ - $\beta$-D-glucan wall microfibrils studied in protoplasts of mutant cells were not impaired. It is suggested that the osmotic fragility of the mutant cells is related to the deficiency of the wall structure as a consequence of the srb1 mutation affecting biogenesis of the amorphous (glucan) component.
\end{abstract}

\section{Introduction}

The cell wall of Saccharomyces cerevisiae consists basically of $\beta$-glucans, chitin and mannoproteins. Microfibrils of $\beta$ - $(1 \rightarrow 3)$-glucan make up the wall fibrillar skeleton (Kopecká et al., 1974; Houwink \& Kreger, $1953)$, which is masked with amorphous $\beta$-glucans (Kopecká et al., 1974) and mannoproteins (cf. Bacon, 1981; Kopecká, 1985). Chitin is largely found in bud scars (Bacon et al., 1966; Cabib et al., 1974, 1982). The wall is an essential component of the yeast cell. Because of its rigidity, it determines cellular shape, enables cell division and prevents lysis of the inner (cytoplasmic) compartment in a hypotonic environment.

Certain mutants of $S$. cerevisiae (in this work referred to as osmofragile cells) are characterized by osmotic fragility, i.e. they grow only in media containing osmotic stabilizers and lyse when transferred into distilled water (Venkov et al., 1974). These mutants share their common characteristic - osmotic fragility in hypotonic media with plant protoplasts. The osmotic fragility of yeast protoplasts is generally caused by the absence of the cell wall; this also prevents protoplast division (cf. Nečas, 1971 ) in liquid media even if these contain an osmotic stabilizer. The osmofragile mutants, on the other hand, divide in the presence of osmotic stabilizers. In contrast to $S$. cerevisiae protoplasts, flattened protoplasts of Schizosaccharomyces japonicus var. versatilis (Gabriel,
1983, 1984), although showing osmotic fragility, can divide in media with osmotic stabilizers. Electron microscopy of the cell walls of Sch. japonicus digested by purified enzymes reveals $\beta$ - $(1 \rightarrow 3)$ - and $\alpha-(1 \rightarrow 3)$-glucan fibrils incompletely masked with amorphous matrix (Gabriel \& Kopecká, 1988).

In osmofragile mutants of $S$. cerevisiae, the fragility is not caused by external conditions affecting the phenotype, as is the case for Sch.japonicus protoplasts (Gabriel, 1984), but is due to mutations in genes whose normal functions are not known. The osmofragile mutant strain VY1160 used in this study has three recessive nuclear mutations: $s r b 1, t s 1$ and $t s 2$. The $s r b 1$ mutation, which determines osmotic fragility, is present in the isogenic, single-mutation strain 193srbl. The $t s 1$ mutation, which increases the tendency of $s r b 1$ cells to lyse, is present alone in the isogenic, single-mutation strain $191 \mathrm{tsl}$. The mutation $t s 2$ is not related to cell fragility but has been found to render the mutant cell sensitive to rifampicin (Venkov et al., 1974, 1975; Kozhina et al., 1979; Stateva \& Venkov, 1981).

The reason for the osmotic fragility of the mutants has been sought in differences in the quality and quantity of wall polymers, as compared to their parental strain. In the osmofragile cells of strain VY1160, an analysis of mannoproteins showed a twofold reduction in mannan. This was due to a significant reduction in the polysaccharide part of the mannoprotein complex and considerably 
shorter mannan side chains (Märkisch et al., 1983; Reuter et al., 1979). A structural analysis of glucan revealed markedly less alkali-soluble glucan and more insoluble glucan which had a higher number of $\beta-(1 \rightarrow 6)$ linkages and a lower molecular mass than that present in the parental cells (Blagoeva \& Venkov, 1990).

The objective of this study was to find out if changes in the biochemistry of wall mannan and glucans would be reflected in an aberrant wall architecture of the mutants detectable at the ultrastructural level. A previous electron microscopic study of ultrathin sections of osmofragile mutant cells suspended in water showed ruptures in the walls through which cellular components leaked out (Mateeva et al., 1976), but this was the only difference from the general ultrastructure of the cell wall typical of a wild-type yeast (Matile et al., 1969). In the present work two additional approaches to electron microscopy were used, namely freeze-etching for studying native walls of whole cells, and metal shadowing for visualizing isolated cell walls. The properties of the glucan fibrillar wall component were investigated in protoplasts derived from osmofragile mutant cells because the yeast protoplast is known to produce a fibrillar glucan skeleton free from amorphous matrix (Kopecká et al., 1965; Kopecká \& Kreger, 1986; Kreger \& Kopecká, $1973,1976 a, b)$.

\section{Methods}

Strains and media. The $S$. cerevisiae strains used in the study are listed in Table 1. The osmofragile mutant VY1160 was derived from the wildtype strain S288C (Venkov et al., 1974). A previous genetic analysis of mutant VY1160 has identified three mutations, $s r b l, t s l$ and $t s 2$, responsible for its phenotype (Venkov et al., 1974, 1975; Kozhina et al., 1979). Three single-mutation strains, 193srbl, 191tsl and 190ts2, were obtained from a cross between strains VY1160 and VY8, the latter being related to the $\mathbf{S} 288 \mathrm{C}$ parental strain. Therefore, the mutant strains were isogenic to both the VY1160 and S288C strains. The genotypes of the isogenic single-mutation strains studied were ascertained by replica plating on appropriate selective media and further confirmed by complementation analysis with tester strains.

All yeast strains were cultivated in a nutrient medium consisting of $80 \%(\mathrm{v} / \mathrm{v})$ malt extract medium and $20 \%(\mathrm{v} / \mathrm{v}) \mathrm{N} 1$ medium $(5$ g glucose, $1.25 \mathrm{~g}$ asparagine, $1.25 \mathrm{~g} \mathrm{KH}_{2} \mathrm{PO}_{4}, 0.425 \mathrm{~g} \mathrm{MgSO}_{4}, 50 \mathrm{ml}$ distilled water; Kelleti et al., 1954), osmotically stabilized with $10 \%(\mathrm{w} / \mathrm{v})$ mannitol ( $\mathrm{pH} 5 \cdot 4$ ). Growth was followed by measuring $\mathrm{OD}_{530}$ in a spectrophotometer at $29-30^{\circ} \mathrm{C}$. Cells growing exponentially were checked by phase-contrast microscopy

Determination of osmotic lysis of mutants. Osmotic fragility was tested in the exponential phase of growth. Aliquots $(1 \mathrm{ml})$ were centrifuged at $670 \mathrm{~g}$ for $5 \mathrm{~min}$, the sediment was washed twice with $5 \mathrm{ml}$ distilled water and, after shaking thoroughly for $1 \mathrm{~min}$ in a microshaker, centrifuged again at $670 \mathrm{~g}$ for $5 \mathrm{~min}$. Methylene blue $(5 \mathrm{ml}, 0 \cdot 01 \%)$ was added, the culture was stirred and the numbers of lysed (blue-coloured) and living (unstained) cells were counted under the microscope.

Cell wall isolation. For electron microscopic observation of the walls, lysed cells were washed three times with distilled water and repeatedly centrifuged at $670 \mathrm{~g}$ for $5 \mathrm{~min}$. The cytoplasm was removed by a sodium
Table 1. Saccharomyces cerevisiae strains used

\begin{tabular}{|c|c|}
\hline Strain & Genotype \\
\hline $\mathrm{S} 288 \mathrm{C}^{*}$ & MAT $\alpha$ gal2 mal \\
\hline VY 1160 & MAT $\alpha$ gal2 mal srbl tsl ts 2 leu 2 tyr thr ade ura \\
\hline VY8 & MATa gal2 mal lys \\
\hline $193 \mathrm{srbl}$ & MATa gal2 mal srbI leu 2 \\
\hline $190 t s 2$ & $M A T \alpha$ gal2 mal ts 2 leu 2 ade \\
\hline $191 t s 1$ & MAT $\alpha$ gal2 mal tsI leu2 lys \\
\hline
\end{tabular}

* Strain S288C was originally obtained from Dr G. Fink, Cornell University, USA.

dodecyl sulphate (SDS) procedure developed by Kopecká (1976) and Kopecká \& Kreger (1986).

Ultrasonic disintegration of cell walls. Treatment for $5 \mathrm{~min}$ at $22 \mathrm{kHz}$ was used to fragment isolated cell walls of both the parental and mutant cells. Wall fragments were washed with distilled water and centrifuged at $670 \mathrm{~g}$ for $15 \mathrm{~min}$.

Protoplast preparation. Exponential-phase cells were washed twice with citrate/phosphate buffer, $\mathrm{pH} 5 \cdot 4$, containing $0.6 \mathrm{M}-\mathrm{KCl}$ and $0.01 \mathrm{M}-\mathrm{MgSO}_{4}$, then treated for $60-120 \mathrm{~min}$ at $29-30{ }^{\circ} \mathrm{C}$ with $40 \%$ snail enzyme solution in citrate/phosphate buffer, $\mathrm{pH} 5.5$, containing $1 \mathrm{M}$ mannitol and $0.01 \mathrm{M}-\mathrm{MgSO}_{4}$. The protoplasts obtained were washed twice by centrifugation at $670 \mathrm{~g}$ with $1 \mathrm{M}$-mannitol and $0.01 \mathrm{M}-\mathrm{MgSO}_{4}$ in citrate/phosphate buffer, $\mathrm{pH} 5.4$. They were transferred to malt extract/N1 medium $(4: 1, \mathrm{v} / \mathrm{v})$ plus $1 \mathrm{M}$-mannitol and grown at 29 $30{ }^{\circ} \mathrm{C}$.

Isolation of glucan fibrillar component. After cultivation for about $24 \mathrm{~h}$, the protoplasts were centrifuged at $670 \mathrm{~g}$ for $10 \mathrm{~min}$ and their cytoplasm removed by extracting with SDS (Kopecká \& Kreger, 1986). Following three washes with distilled water, isolated fibrillar nets were placed on grids and prepared for examination by electron microscopy.

Freeze-etching of cells and protoplasts. Freeze-etched replicas were prepared from cells growing exponentially in nutrient medium with $10 \%(\mathrm{w} / \mathrm{v})$ mannitol at $29-30{ }^{\circ} \mathrm{C}$ by centrifugation at $670 \mathrm{~g}$ for $6 \mathrm{~min}$. The pellets of living yeast cells were transferred to copper grids, then frozen in Freon 22 and liquid nitrogen. Replicas were prepared after fracturing at $-100^{\circ} \mathrm{C}$ in a Balzers BA $360 \mathrm{M}$ apparatus essentially according to the procedure of Moor \& Mühlethaler (1963). The etching time was $1 \mathrm{~min}$.

Electron microscopy. Washed isolated cell walls were applied to copper grids covered with Formvar films. After drying, the walls were shadowed with platinum under vacuum. Metal-shadowed preparations and freeze-etched replicas were studied and photographed with a Tesla BS 500 electron microscope.

\section{Results}

Cell proliferation, morphology and osmotic fragility
testing

The cells of the parental strain $\mathrm{S} 288 \mathrm{C}$ proliferated at a higher rate at $29-30^{\circ} \mathrm{C}$ than the mutant strain VY 1160 ; the generation times were 100 and $220 \mathrm{~min}$, respectively (Fig. 1). 


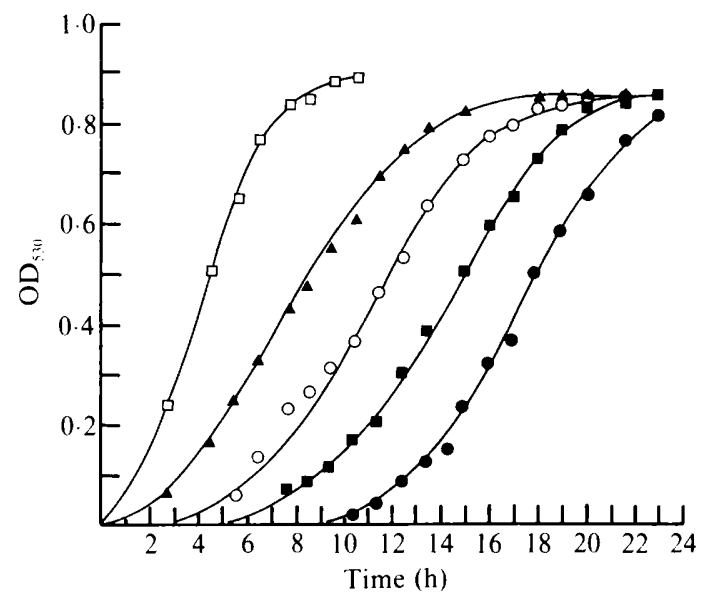

Fig. 1. Growth $\left(\mathrm{OD}_{530}\right)$ of the parental S288C and mutant VY1160 strains. The proliferation of VY1160 cells at a dilution of $1: 100(\mathbb{\square})$ is much slower than that of S288C cells at the same dilution ( $\square$ ), which reach the stationary phase in $10 \mathrm{~h}$ while the VY1160 strain does so only after $22 \mathrm{~h}$. $\mathbf{\Delta}$, VY1160, dilution $1: 25$; O, VY1160, dilution $1: 50$; VY1160, dilution $1: 100$;, VY1160, dilution $1: 200$.

Light microscopy observations showed that cells of the wild-type S288C in the exponential phase had the normal appearance of ovoid budding cells of $S$. cerevisiae (Fig. $2 a$ ) while cells of the mutant VY1160 were more rounded in shape (Fig. $2 b$ ). When tested for osmotic fragility, the parental S288C strain was stable and the majority of cells were viable after repeated washing with distilled water. The mutant VY1160 cells, on the other hand, were mostly dead and stained with methylene blue when examined after repeated washing with distilled water (Table 2).

\section{Electron microscopy of cell walls}

The fact that VY1160 cells died following transfer to distilled water opened up the possibility of isolating a pure wall fraction simply by washing the cells repeatedly with distilled water. It appeared, however, that this procedure was effective only in a small portion of the cell population, probably due to wall ruptures; most of the cells retained their cytoplasm either partially or completely.

Cells of VY 1160 were treated with $0.5 \%$ SDS, which is reported to remove cytoplasm from regenerating protoplasts. The walls obtained were observed in the electron microscope and found to have amorphous surfaces typical of yeast cell walls (Fig. $2 d$ ). Both mother and bud walls were mostly isodiametrical in shape, and the bud scars had a normal appearance. Cell wall ruptures were observed rarely (not shown). Attempts to isolate cell walls from strain S288C under the same conditions failed. SDS concentrations of $5 \%$ and $10 \%$ had to be used
Table 2. Viability of cells of strains S288C, VY1160, 190ts2 and 193srbl after repeated washing with distilled water and staining with methylene blue

\begin{tabular}{lcc}
\hline \hline Strain & $\begin{array}{c}\text { No. of cells } \\
\mathrm{ml}^{-1}\end{array}$ & $\begin{array}{c}\text { Percentage of } \\
\text { living cells } \\
\text { (unstained) }\end{array}$ \\
\hline S288C & $2.3 \times 10^{7}$ & 98.0 \\
& $4.8 \times 10^{8}$ & $96 \cdot 6$ \\
VY1160 & $8.25 \times 10^{7}$ & 82.0 \\
& $5.6 \times 10^{6}$ & 27.2 \\
$190 t s 2$ & $4.75 \times 10^{6}$ & 6.6 \\
$193 \mathrm{srbl}$ & $6.25 \times 10^{6}$ & 10.0 \\
\hline \hline
\end{tabular}

repeatedly (twice each) before a major proportion of walls could be purified (Fig. 2c). After treatment with $10 \%$ SDS the wild-type cells differed in shape from the mutant cells on electron microscopic examination, being ovoid as opposed to isodiametrical. Occasional cells of the mutant strain showed ruptures in their walls.

Isolated cell walls were subjected to disintegration with ultrasound and their inner surfaces were investigated. In the parental strain S288C, these surfaces had the typical amorphous appearance of intact yeast cell walls (Fig. 2e). In the mutant VY1160, the inner wall surfaces revealed the fibrillar component exposed due to a decrease in the amount of amorphous matrix (Fig. $2 f$ ).

\section{Freeze-etching of cells}

The inner ultrastructure of cells shown in freeze-etched replicas did not differ between the parental S288C and the mutant VY1160 strains. It was in agreement with the normal picture of budding $S$. cerevisiae cells described by Moor \& Mühlethaler (1963). Each cell possessed a nucleus with a nuclear envelope and pores, mitochondria, endoplasmic reticulum, vacuoles and also lipid droplets. The Golgi apparatus was not observed.

The cell surfaces, however, showed distinct differences in ultrastructure between the parental strain and the osmofragile mutant. In an attempt to relate these differences to one of the three mutations present in the osmofragile mutant VY1160, freeze-etched replicas of each of the isogenic, single-mutation strains were studied. Cells of S288C as well as both osmotically stable single-mutation strains 191 ts 1 and $190 t s 2$ had ridges on the EF face of the plasma membrane (Fig. $3 a$ ), and invaginations and numerous hexagonally-arranged integral membrane particles densely spread over the PF face of the plasma membrane (Fig. $3 b$ ), as is typical for wildtype yeasts. The VY1160 mutant, on the other hand, 

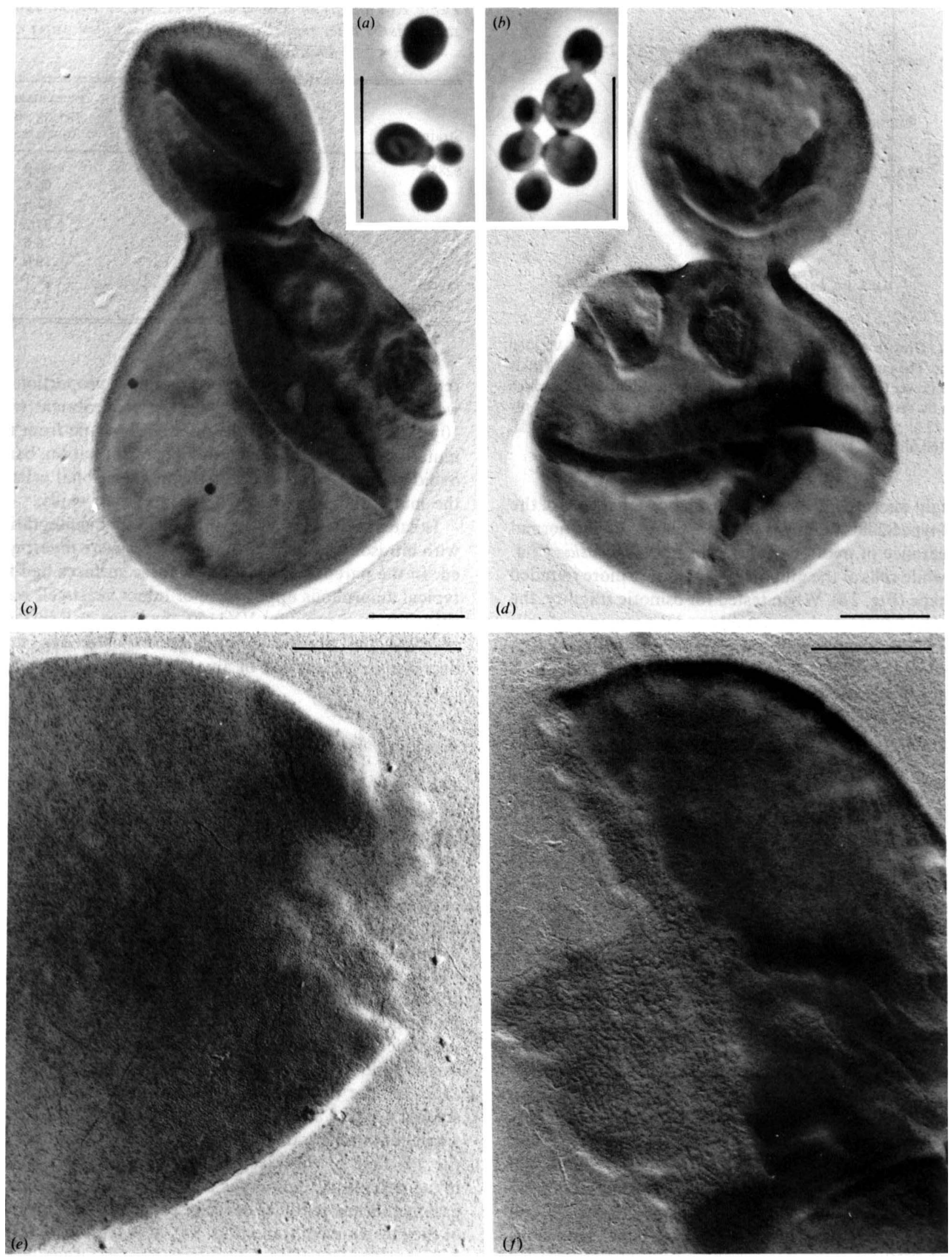
exhibited a net-like structure on the EF face of the plasma membrane (Fig. $3 c$ ) which penetrated through the EF face into the cell interior. The prominent network was reminiscent of the thick glucan fibrillar skeleton made by protoplasts (see Fig. 4) and of that seen on the inner surface of isolated cell walls (see Fig. $2 f$ ). The PF face bore invaginations and impressions (Fig. $3 d$ ) which corresponded to the prominent structures on the EF face (Fig. $3 c$ ). The osmofragile single-mutation $193 \mathrm{srbl}$ cells showed a marked net-like structure on the EF face of the plasma membrane (Fig. 3e), which was analogous to that in the VY1160 cells (Fig. 3c), and its imprint on the PF face (Fig. $3 f$ ), which could not be distinguished from that on the PF face of the plasma membrane in VY1160 cells (Fig. $3 d$ ).

\section{Fibrillar glucan component of protoplast walls}

To gain a deeper insight into the characteristics of the cell wall structures in osmofragile mutant cells, protoplasts were employed, because in the process of cell wall regeneration in liquid media $S$. cerevisiae protoplasts are known to produce a fibrillar glucan wall component free from amorphous matrix (Kopecká et al., 1965; Kreger \& Kopecká, 1973, 1976a, b; Kopecká \& Kreger, 1986). Protoplasts of all four strains investigated, viz. S288C, VY1160, 193srbl and 190ts2, produced glucan-based fibrillar wall components. No differences were found at the ultramicroscopical level in either appearance or structure between the osmofragile mutants (Fig. 4a) and the parental strain S288C (Fig. $4 b$ ) or the osmotically resistant mutant 190ts2 (not shown).

\section{Discussion}

The method of wall isolation used in this study was based on treatment with SDS. It appeared that the cell walls of mutant VY1160 were more permeable to cytoplasmic polymers than those of the wild-type, as the concentration of SDS required for their permeabilization $(0.5 \%)$ was 20-fold lower. This finding was suggestive of differences in the wall characteristics. An increase in permeability of cell walls for cytoplasmic biopolymers has already been reported in strain VY1160 by Philipova \& Venkov (1990). Electron microscopy after disintegra- tion with ultrasound showed that the inner surface of the cell wall in cells of the mutant VY1160 was markedly different from that of the parental strain. It was characterized by a fibrillar texture that was apparently due to a very low degree of masking by amorphous matrix (Fig. $2 f$ ). The inner surface of the S288C cell walls, on the other hand, had a typical amorphous appearance (Fig. 2e).

The fibrillar wall component was also demonstrated in freeze-etched replicas of whole cells in the osmofragile mutant VY1160 and in the single-mutation strain $193 \mathrm{srbl}$. However, only thick bundles of glucan microfibrils were prominent and seen on both the EF and PF faces of the plasma membrane. The finding of unmasked fibrillar structures in the walls of native cells has not, to our knowledge, been reported before in any other $S$. cerevisiae cells studied by freeze-etching.

However, no fibrillar wall structures were detected by freeze-etching in either the S288C strain or singlemutation strains $190 t s 2$ and 191 tsl, both of which are resistant to osmotic changes (Table 2). These results imply a relation between an unmasked fibrillar network on the inner wall surface and the osmotic fragility of the mutant cell. The exposed fibrillar network in cells of VY1160, which bear $s r b l, t s l$ and $t s 2$ mutations, and in the single-mutation strain $193 \mathrm{srbl}$, suggests that it is a phenotypic expression of the $s r b 1$ mutation. It can be further speculated that this mutation is responsible for the synthesis of a mutant or aberrant glucan, and that consequently, this incomplete material cannot ensure the formation of a complete amorphous matrix. Blagoeva \& Venkov (1990), studying the structure of glucans making up the cell wall of the VY1160 mutant, found a significant decrease in the amount of alkali-soluble glucan. This provides complementary biochemical evidence for a decreased quantity of amorphous matrix.

The quality of the glucan fibrillar network was studied in protoplasts prepared from both the wild-type and the mutant strains. No differences were found in the ultrastructure of the fibrillar wall component between the strains studied, indicating that the glucan microfibrils were undisturbed and similar in composition. Their electron microscopic images at the magnification used in the study showed no evidence of the chemical changes in insoluble glucans, namely a lower molecular mass and a higher number of $\beta$-( $1 \rightarrow 6)$-linkages, found in cells of VY1 160 cells by Blagoeva \& Venkov $(1990 a, b)$. It

Fig. 2. Yeast cells and cell walls. $(a, b)$ Phase-contrast micrographs of cells of S288C $(a)$ and VY1160 $(b)$ growing on the surface of $2 \%$ agar. $(b-f)$ Electron micrographs of isolated cell walls of S288C $(c, e)$ and VY1160 $(d, f)$. In $(c)$, cytoplasm was removed by treatment with $0.5 \% \mathrm{SDS}$ for $10 \mathrm{~min}$ at $50{ }^{\circ} \mathrm{C}$, followed by $5 \%$ and $10 \% \mathrm{SDS}$ and washing with water. This procedure was repeated twice with each SDS concentration. In $(d)$ the procedure was the same except that the treatments with $5 \%$ and $10 \%$ SDS were omitted. In $(e)$ and $(f)$ the cell walls were isolated by ultrasonic disintegration. All samples for electron microscopy were shadowed with platinum. Bars represent $10 \mu \mathrm{m}(a, b)$ and $1 \mu \mathrm{m}(c-f)$. 

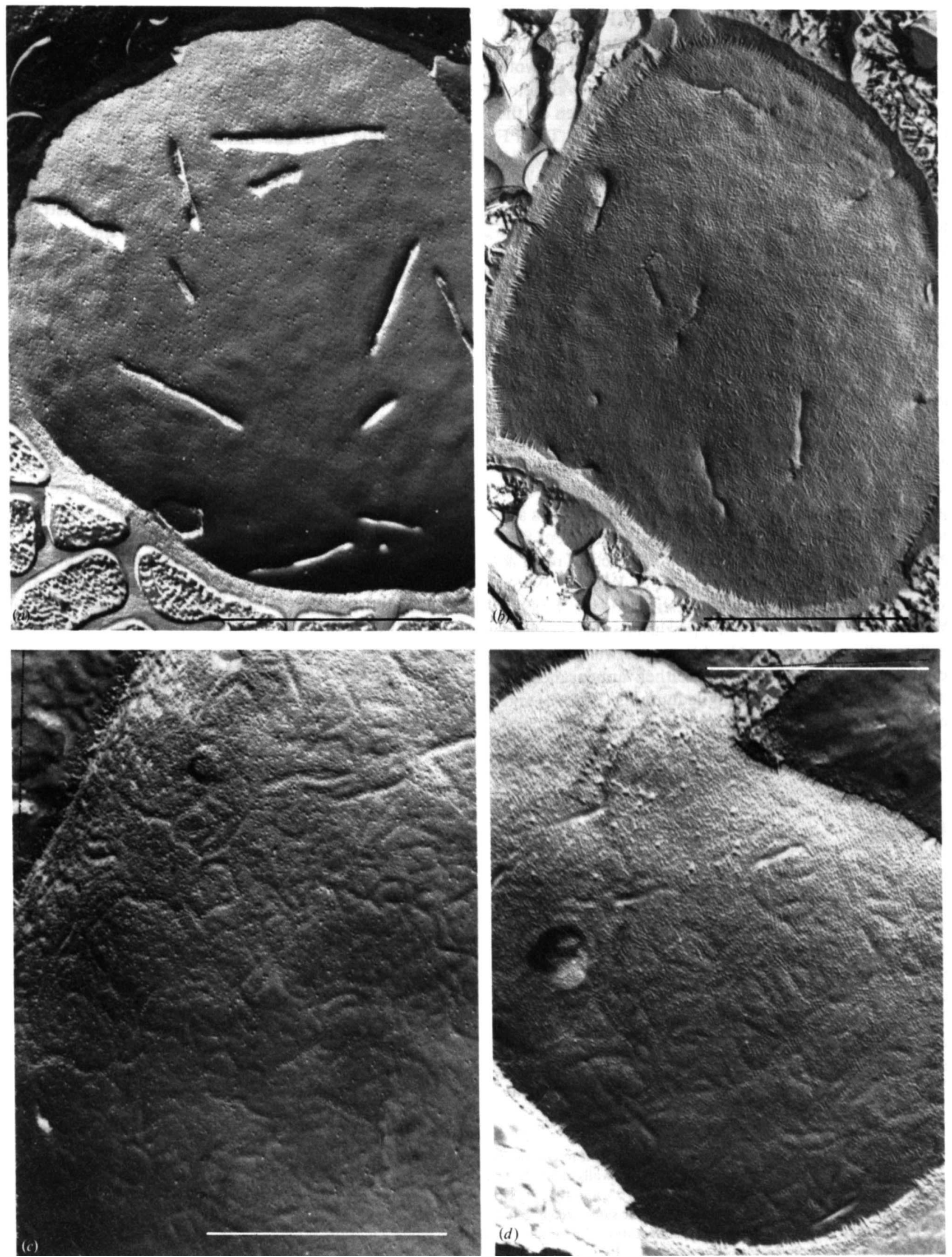

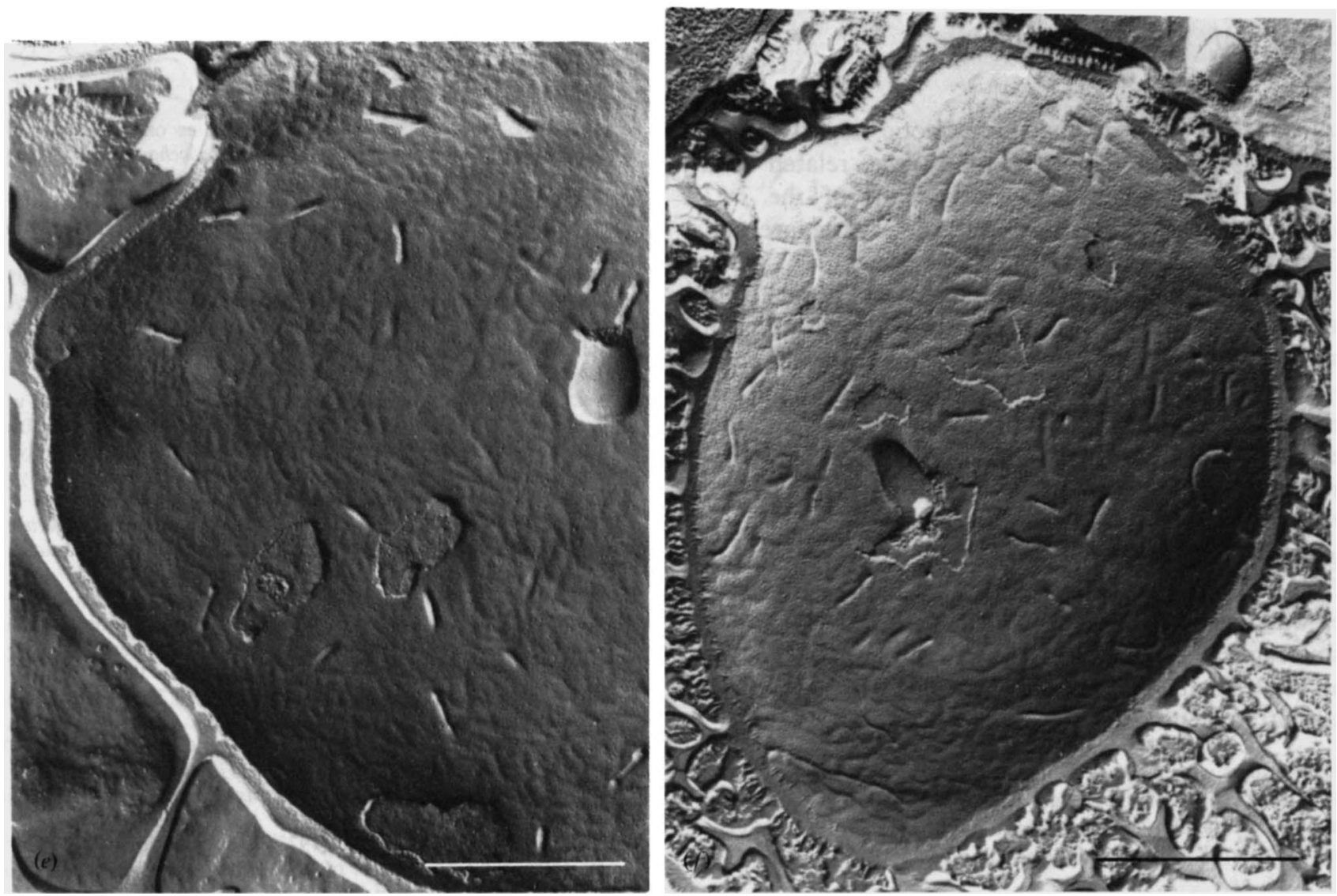

Fig. 3 (contd from previous page). Electron micrographs of freeze-etchings of the plasma membrane (freeze-etching terminology according to Branton et al., 1975). (a) Exoplasmic fracture (EF) face of strain 190ts2; (b) protoplasmic fracture (PF) face of strain $190 t s 2 ;(c)$ EF face of strain VY1160; (d) PF face of strain YV1160; $(e)$ EF face of strain 193srbl; $(f)$ PF face of strain 193srb1. Bars represent $1 \mu \mathrm{m}$.
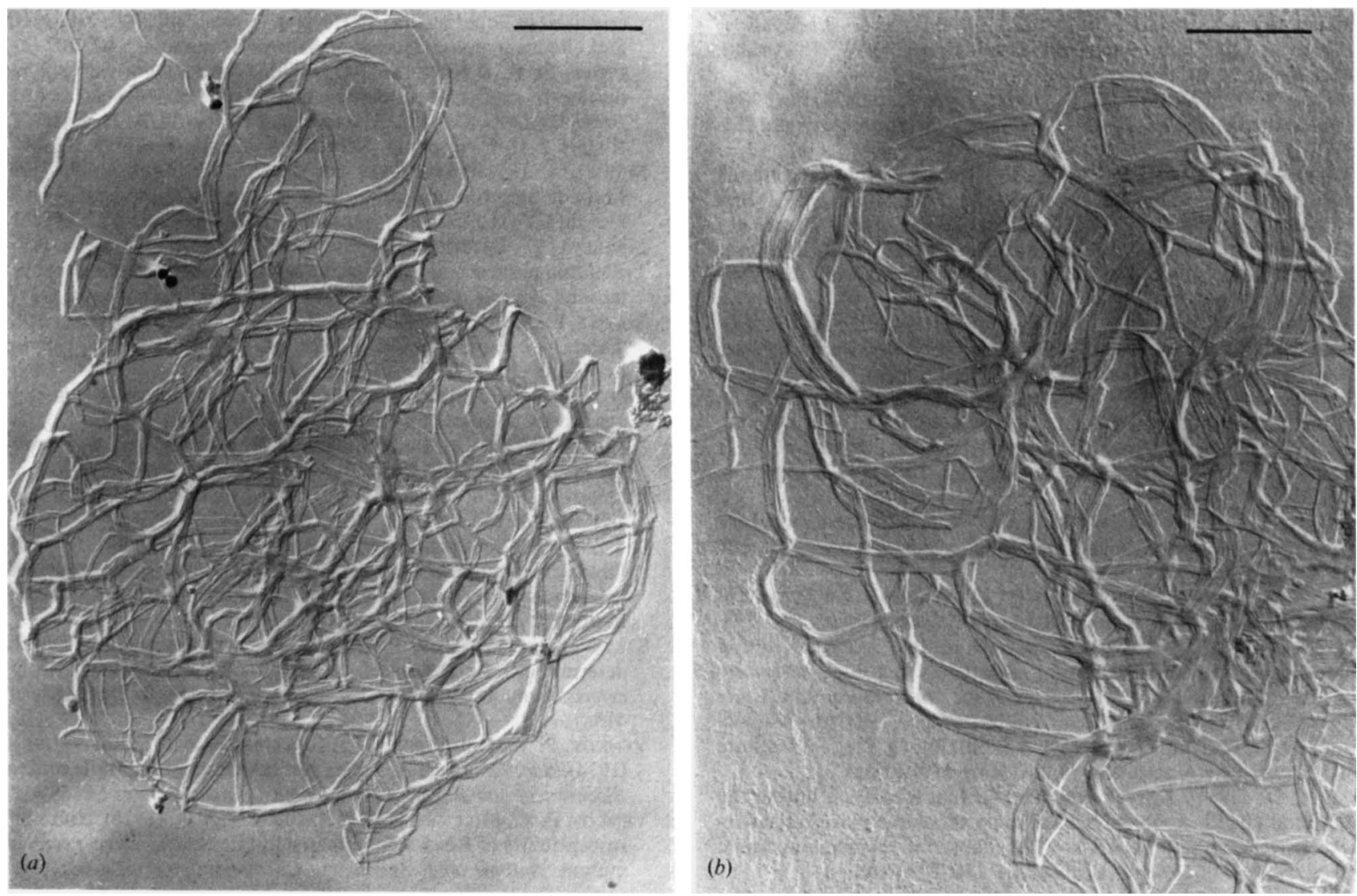

Fig. 4. Electron micrographs of the fibrillar glucan wall component formed by protoplasts of strain S288C (a) and strain VY1160 (b). Shadowed with platinum. Bars represent $1 \mu \mathrm{m}$. 
can thus be concluded that the osmotic fragility manifested by cells of mutant VY1160 was related to a deficiency occurring, as a consequence of the srbl mutation, during biogenesis of the wall structure and affecting its amorphous (glucan) component.

Evidence that an incomplete cell wall can be related to osmotic fragility without interfering with cell division has been provided by studies of dividing Schizosaccharomyces japonicus protoplasts (Gabriel, 1984). The low amount of amorphous matrix found in their incomplete cell walls does not mask the fibrillar wall skeleton properly, and the resulting three-dimensional wall architecture lacks the rigidity necessary for protection against lysis. However, while in the flattened protoplasts of Sch. japonicus the wall fragility is due to the incomplete cell wall regeneration (Gabriel \& Kopecká, 1988), in the osmofragile $S$. cerevisiae cells (VY1160 and 193srbl) it can be attributed to a genetically-coded deficiency in the wall ultrastructure.

The authors wish to thank Ladislav Hodeček, Helena Dobrovolna and Zuzana Cajková, biology students, for their assistance in some of the experiments. For technical assistance thanks are due to Verra Vinařická, Jan Krobauer and Jiřina Drápalová

\section{References}

BACON, J. S. D. (1981). Nature and disposition of polysaccharides within the cell envelope. In Yeast Cell Envelopes: Biochemistry, Biophysics and Ultrastructure, pp. 65-84. Edited by W. N. Arnold. Boca Raton: CRC Press.

Bacon, J. S. D., Davidson, E. D., Jones, D. \& TAYLoR, I. F. (1966). The location of chitin in the yeast cell wall. Biochemical Journal 101, $36 \mathrm{C}-38 \mathrm{C}$.

Blagoeva, J. \& Venkov, P. (1990a). Cell surface structures in fragile mutants of Saccharomyces cerevisiae. In Proceedings of the 14th International Specialized Symposium on Yeasts 'Yeast Taxonomy: Theoretical and Practical Aspects', pp. 42-44. Edited by A. KockováKratochvílová. Smolenice: Institute of Chemistry, Slovak Academy of Sciences, Bratislava.

Blagoeva, J. \& Venkov, P. $(1990 b)$. Decreased synthesis of alkalisoluble glucan in a cell-wall mutant of Saccharomyces cerevisiae. Biochemistry International 22, 791-795.

Branton, D., Bullivant, S., Gilula, N. B., Karnovsky, M. J., Moor, H., Mühlethaler, K., Northcote, D. H., Packer, L., Satir, B., Satir, P., SPeth, V., Staehelin, L. A., Steere, R. L. \& WEINSTEIN, R. S. (1975). Freeze-etching nomenclature. Science 190 , 54-56.

Cabib, E., Ulane, R. \& Bowers, N. (1974). A molecular model for morphogenesis: the primary septum of yeast. Current Topics in Cellular Regulation 8, 1-32.

CABIB, E., ROBERTS, R. \& BowERs, B. (1982). Synthesis of the yeast cell wall and its regulation. Annual Review of Biochemistry 51, 763-793.

GABRIEL, M. (1983). Karyokinesis and cell septum formation during incomplete cell wall regeneration in flattened Schizosaccharomyces versatilis protoplasts. In Proceedings of the 6th European Cell Cycle Workshop 'Progress in Cell Cycle Controls', Prague, 1983, pp. 144-146. Edited by J. Chaloupka, A. Kotyk \& E. Streiblová. Prague: Institute of Microbiology, Czechoslovak Academy of Sciences.

GABRIEL, M. (1984). Karyokinesis and septum formation during the regeneration of incomplete cell walls in protoplasts of Schizosaccharomyces japonicus var. versatilis: a time-lapse microcinematographic study. Journal of General Microbiology 130, 625-630.
GABRIEL, M. \& KoPECKÁ, M. (1988). Studies on cell division in regenerating protoplasts of the yeast Schizosaccharomyces japonicus. Journal of General Microbiology 134, 2029-2037.

HouwINK, A. L. \& KREGER, D. R. (1953). Observations on the cell wall of yeasts. An electron microscope and X-ray diffraction study. Antonie van Leeuwenhoek 19, 1-24.

Kelleti, T., Szabolzi, G., Lenvai, A. \& Garzo, T. (1954). Untersuchungen über die lebens fähigen Eiweisskörper von Saccharomyces cerevisiae. Die Regeneration in sterilen Filtrat von zerstorten Hefezellen. Acta Scientifica Academiae Scientiarum Hungaricae 5, 213-217.

KOPECKÁ, M. (1976). Biogenesis of the fibrillar wall component in yeast protoplasts. PhD thesis (in Czech), J. E. Purkyně University Brno.

KOPECKÁ, M. (1985). Electron microscopic study of purified polysaccharide components glucan and mannan of the cell walls in the yeast Saccharomyces cerevisiae. Journal of Basic Microbiology 25, 161-174.

KOPECKÁ, M. \& KREGER, D. R. (1986). Assembly of microfibrils in vivo and in vitro from $(1 \rightarrow 3)$ - $\beta$-D-glucan synthesized by protoplasts of Saccharomyces cerevisiae. Archives of Microbiology 143, 387-395.

KOPECKÁ, M., ČTVRTNíČEK, O. \& NEČAS, O. (1965). Formation and properties of the fibrillar network formed in yeast protoplasts as the first step of biosynthesis of cell wall. Symposium über HefeProtoplasten, Jena, pp. 73-75. Berlin: Akademie Verlag.

Kopecká, M., Phaff, H. J. \& FleEt, G. H. (1974). Demonstration of a fibrillar component in the cell wall of the yeast Saccharomyces cerevisiae and its chemical nature. Journal of Cell Biology 62, 66-76.

Kozhina, T., Stateva, L. \& VenKov, P. (1979). Genetic analysis of an osmotic sensitive Saccharomyces cerevisiae mutant. Molecular and General Genetics 170, 351-354.

KREGER, D. R. \& KopeCKÁ, M. (1973). On the nature of the fibrillar nets formed by protoplasts of Saccharomyces cerevisiae in liquid media. In Yeast, Mold and Plant Protoplasts. Proceedings of the Third International Symposium on Yeast Protoplasts, Salamanca, pp. 117130. Edited by J. R. Villanueva, I. Garcia-Acha, S. Gascón \& F. Uruburu. London: Academic Press.

KREGER, D. R. \& KOPECKÁ, M. (1976a). On the nature and formation of the fibrillar nets produced by protoplasts of Saccharomyces cerevisiae in liquid media : an electron microscopic, X-ray diffraction and chemical study. Journal of General Microbiology 92, 207-221.

KREGER, D. R. \& KOPECKÁ, M. (1976 b). Assembly of wall polymers during the regeneration of yeast protoplasts. In Microbial and Plant Protoplasts, pp. 237-252. Edited by J. F. Peberdy, A. H. Rose, H. J. Rogers \& E. C. Cocking. London: Academic Press.

Märkisch, U., Reuter, G., Stateva, L. \& Venkov, P. (1983). Mannan structure analysis of the fragile Saccharomyces cerevisiae mutant VY1160. International Journal of Biochemistry 15, 1373-1377.

Mateeva, Z., Petrov, P., Venkov, P. \& Hadjolov, A. A. (1976). Electron microscopic study of the lysis of an osmotic-sensitive yeast mutant. Journal de Microscopie et de Biologie Cellulaire 26, 73-74.

Matile, P., MoOR, H. \& Robinow, C. F. (1969). Yeast cytology. In The Yeasts, vol. 1, pp. 219-297. Edited by A. H. Rose \& J. S. Harrison. London \& New York: Academic Press.

MOOR, H. \& MüHLETHALER, K. (1963). Fine structure in frozen-etched yeast cells. Journal of Cell Biology 17, 609-628.

NEČAS, O. (1971). Cell wall synthesis in yeast protoplasts. Bacteriological Reviews 35, 149-170.

Philipova, D. H. \& Venkov, P. V. (1990). Cell fusion of Saccharomyces cerevisiae fragile mutants. Yeast 6, 205-212.

REUTER, G., MärkisCH, U., HERING, V. \& VeNKov, P. (1979). Unterschiedliche Zusammensetzung der Zellwand-Polysaccharide bei Saccharomyces cerevisiae S288C und einer osmolabilen Mutante. Zeitschrift für Allgemeine Mikrobiologie 19, 411-414.

Stateva, L. \& VenKov, P. (1981). Meiotic mapping of the nuclear determinant of cell lysis of the osmotic dependent Saccharomyces cerevisiae mutant VY1160. Molecular and General Genetics 181, 414415.

Venkov, P. V., Hadjiolov, A. A., Battaner, E. \& Schlezinger, D. (1974). Saccharomyces cerevisiae sorbitol dependent fragile mutants. Biochemical and Biophysical Research Communications 56, 599-604.

VenKov, P. V., MilcheV, G. I. \& HaDjIolov, A. A. (1975). Rifampicin susceptibility of RNA synthesis in a fragile Saccharomyces cerevisiae mutant. Antimicrobial Agents and Chemotherapy 8, 627-632. 